\title{
Evaluation of the Lower Urinary Tract Symptoms and Erectile Dysfunction with Uroflowmetry, IPSS and IIEF Questioniares
} Uroflovmetri, UPSS ve UEIFSorgulama Formları ile Erektil Disfonksiyon ve
Alt Üriner Semptomlarının Değerlendirilmesi

\author{
Levent Verim1, Asıf Yıldıım2, Erol Peltekoğlu2, Erem Kaan Başok3, Sarp Korcan Keskin4, \\ Cengiz Çanakcı5
}

\author{
1Haydarpaşa Numune Training and Research Hospital, Clinic of Urology, İstanbul, Turkey \\ 2 Medeniyet University Faculty of Medicine, Göztepe Training and Research Hospital, Clinic of Urology, İstanbul, Turkey \\ 3 Bahçeşehir University Faculty of Medicine, Göztepe Medicalpark Hospital, Clinic of Urology, Istanbul, Turkey \\ 4 Emsey Private Hospital, Clinic of Urology, İstanbul, Turkey \\ 5Bolvadin State Hospital, Clinic of Urology, Afyon, Turkey
}

\section{What's known on the subject? and What does the study add?}

The aim of the present study was to emphasise the problems of Turkish geriatric patients and to carry a step forward their quality of life.

\section{ABSTRACT}

Objective

This study was conducted to investigate the relationship between lower urinary tract symptoms (LUTS) and erectile dysfunction (ED) in aging men. The population of elderly men in Turkey has increased through last two decades. Therefore, problems of aging men had found growing scientific attention in our country. In this study, we investigated the association between LUTS and $E D$, while considering the other concomitant factors for ED, including severity of urinary symptoms according to uroflowmetric measurements.

\section{Materials and Methods}

A cross-sectional study was carried out with 213 consecutive male subjects. Age, blood analysis and uroflowmetry scores were evaluated. All patients completed the International Index of Erectile Function (IIEF) form and International Prostate Symptom Score (IPSS) (reflecting LUTS) questionnaires.

\section{Results}

The eligible patients with a mean age of $60.38 \pm 7.53$ years were enrolled in this study. ED was reported in $66(31 \%)$ patients according to IIEF scores. Severe prostate symptoms according to the IPPS scores were compatible with the severity of uroflowmetry measurements. Overall IPSS scores were significantly associated with ED $(p<0.01)$. In addition, an association between the severity of ED and LUTS was observed $(p<0.05)$. The mean quality of life assessment in the IPSS revealed a statistically significant difference between individuals with varying degrees of ED $(p<0.01)$.

\section{ÖZET}

Amaç

Bu çalışma, toplumumuzda sayısı giderek artan yaşlanan erkeklerin alt üriner sistem semptomları (AÜSS) ile erektil disfonksiyonun (ED) ilişkisinin araştırılması hedeflenmektedir.

Gereç ve Yöntem

Burada, enine kesit çalışma ile 213 uygun erkek hasta incelenmiştir. Bütün hastalar, Uluslararası Erektil iş̧lev Formu (UEiF) ve Uluslararası Prostat Semptom Skor (UPSS) sorgulama formlarını doldurmuş, yaş, kan analizleri ve üroflovmetri ölçümleri kaydedilmiştir.

Bulgular

Hastaların ortalama yaşı 60,38 $\pm 7,53$ bulundu. ED, 66 (31\%) hastada saptandı. Ağır UPSS sayıları ile üroflovmetri ölçümleri uyumlu bulundu. Genel olarak UPSS ile ED ağır ölçümleri arasındaki ilişki istatistiksel olarak önemli bulundu $(p<0,01)$. Ayrıca ED ciddiyet artışı ile AÜSS ağırlığı ilişkili bulundu $(p<0,05)$. UPSS'deki ortalama yaşam kalitesi (OYK) ölçümleri ile değişen oranlarda ED'i olan bireylerin kendi aralarında istatistiksel farklılık saptandı $(p<0,01)$.

Sonuç

Toplumumuzda artan yaşla doğru orantılı olarak, ağır AÜSS bulguları ve seksüel fonksiyon herbiri bağımsız olarak diğerini etkileyen hastalık 


\begin{abstract}
Conclusion

The relationship between increasing LUTS severity and sexual dysfunction is independent of the impact of comorbid conditions and increasing age. Sexual history and therapeutic management of ED are important in aging men for better quality of life.
\end{abstract}

\section{Key Words}

Erectile dysfunction, lower urinary tract symptoms, quality of life, uroflowmetry

\section{ÖZET}

durumlarıdır. Cinsel öykü alınması ve varsa ED tedavisi yaşlanan erkeğin yaşam kalitesini arttırmada önemlidir.

\section{Anahtar Kelimeler}

Erektil disfonksiyon, alt üriner sistem semptomları, yaşam kalitesi, üroflovmetri

\section{Introduction}

The population of elderly men in Turkey has increased over the last two decades. Therefore, problems of aging men had found growing scientific attention in our country. Among various physical changes observed in aging men, lower urinary tract symptoms (LUTS) are the most common complaints together with irritative and obstructive symptoms. LUTS are an aggregate of voiding symptoms, including pollakiuria, nocturia, intermittency, hesitancy, urgency and slow and weak stream, and are frequently caused by benign prostatic hyperplasia (BPH) (1). Sexual dysfunctions, including erectile dysfunction (ED) and/ or ejaculatory disorders (EjD) and decreasing sexual activity are also widespread problems in aging men. ED is defined as the consistent inability to achieve or maintain a penile erection of sufficient quality to perform satisfactory sexual intercourse. Conditions, such as diabetes mellitus (DM), hypertension (HT) and hyperlipidemia, the prevalence of which tends to increase with age, are also associated with sexual dysfunction. The high prevalence of ED and LUTS may explain the coincidence of ED and LUTS in elderly men. Recently, various theories have been proposed about the pathophysiological pathways between LUTS and ED, including the presence of pelvic atherosclerosis, autonomic hyperactivity, reduced production of nitric oxide in the prostate and penis, increased Rho-kinase activation and endothelia activity, and influences of the metabolic syndrome (2). Metabolic syndrome with an increased body mass index (BMI) score is also associated with a higher prevalence of irritative and obstructive LUTS $(3,4)$. In this study, we investigated the association between LUTS and ED, while considering the other concomitant factors for ED, including severity of urinary symptoms according to uroflowmetric measurements.

\section{Materials and Methods}

The study was approved by our hospital's Research Ethics Committee. A cross-sectional study was carried out with 213 consecutive male subjects (aged between 39 and 79 years) and they all had bothered of LUTS. The participants were evaluated routinely for clinical history and aprompt physical examination was performed. A fasting blood sample was obtained from all subjects, and glucose, total cholesterol, high-density lipoprotein (HDL), low-density lipoprotein (LDL), and triglycerides were determined, all in the laboratory at our hospital. Patients with a previous history of DM and/or HT were also included in our study. Exclusion criteria included a previous diagnosis of prostate cancer, neurological disorders, acute urinary infection and a previous prostatic surgery. Age and uroflowmetry scores were recorded. Uroflow measurements of the patients associated with severe ED were evaluated with a maximum urinary flow (0max) of more than $15 \mathrm{ml} / \mathrm{s}$ and less than $10 \mathrm{ml} / \mathrm{s}$. The patients were also given written instructions on how to perform timed micturition measurements (length of time in seconds required to void the first $100 \mathrm{ml}$ of urine). All patients completed the International Index of Erectile Function (IIEF) form and International Prostate Symptom Score (IPSS) questionnaire. The 15item IIEF were divided into five domains of sexual function: erectile function ( 6 items), orgasmic function (2 items), sexual desire (2 items), intercourse satisfaction (3 items), and overall satisfaction (2 items).

More recently, IIEF 5-item version (IIEF-5), of the form is used as diagnostic tool for ED. We used the sum of the IIEF-score for the 1-5 to 15th questions allowed to classify the patients into the three classes for evaluation of erectile domain. The patients were divided into three classes: severe erectile dysfunction (total score $<11$ ), moderate erectile dysfunction (total score: 11-21), mild erectile dysfunction (total score: 21-25) and no erectile function ( $>25$ ). The optimal cut-off score of IIEF was 25 , with men scoring $\leq 25$ classified as having ED and those scoring above 25 as not having ED (5). The participants completed a self-administered IPSS questionnaire regarding LUTS severity (6). IPSS is divided into three domains: obstructive symptom (incomplete emptying, weak stream, intermittency, and straining), irritative symptom (urgency, voiding frequency, and nocturia), and IPSS-QoL. The total score of seven IPSS questions allowed to classify the patients into the low score range (0-7), intermediate score range (8-19), and high score range (20-35). The 8th question, regarding the patient's quality of life $(\mathrm{OoL})$, was considered separately, with a score ranging from 1 to 6 (0-delighted to 6-terrible). Correlations between the total score and each domain of IIEF and of IPSS were analyzed. Correlations of age with 0 Max in the uroflowmetry and IIEF were also investigated.

\section{Statistical Analysis}

NCSS (Number Cruncher Statistical System) 2007\&PASS (Power Analysis and Sample Size) 2008 Statistical Software (Utah, USA) was used for statistical analysis. The methods of descriptive statistics such as mean, standard deviation, frequency, ratios, etc. were used in the study. The one-way ANOVA test was used for comparing three or more groups and Tukey's HSD test was used to evaluate the differentiated groups in the case of normally distributed variables and the KruskalWallis test otherwise. The relationship between IPSS and IIEF was compared using Pearson correlation coefficient and Spearman's correlation analysis. $P$ values of $p<0.01$ and $p<0.05$ were considered statistically significant. 


\section{Results}

Table 1 shows the demographic and clinical data of the subjects. A total of 213 eligible patients with a mean age of $60.38 \pm 7.53$ years were enrolled in this study. The mean IIEF score was found to be $14.9 \pm 8.10$ (1-25), and the mean IPSS was 8.4 \pm 6.8 (0-32). ED (moderate or severe) was reported in $66(31 \%)$ patients according to IIEF scores with a mean of $14.9 \pm 8.10$. The mean $\mathrm{QMax}$ level in uroflowmetry was found to be $2.76 \pm 1.51 \mathrm{ml} / \mathrm{sec}$. The median timed micturition was found to be $33.47 \pm 6.86$ seconds. The mean QoL score was defined as $3.48 \pm 1.35$ according to the results of the 8 th question of the IPSS questionnaire. There was no comorbities in $62 \%(n=132)$ of cases. HT in 22\% of cases ( $n=47)$, DM in $8.5 \%(n=18)$ and $H T$ accompanied with DM in $7.5 \%$ of cases $(n=16)$ were defined in the study. HT and/or DM comorbidities were accompanied with ED and non-ED conditions in $34 \%$ (50/147 cases) and 45\% of cases (30/66 cases), respectively. The comorbid conditions in subjects with and without ED are shown in Table 2. Patients with mild and moderate IPSS had severe ED [11\% (4 cases) and $8 \%$ (10 cases), respectively]. IPSS were low, intermediate,

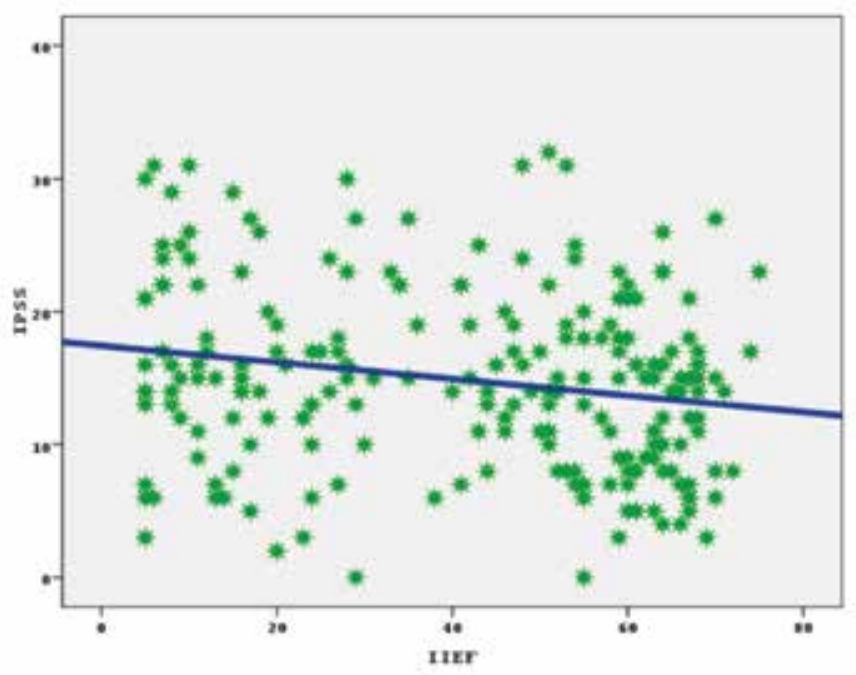

Figure 1. Negative corelation between IPSS and IIEF scores $(r=-0.198$; $p=0.004 ; p<0.01)$

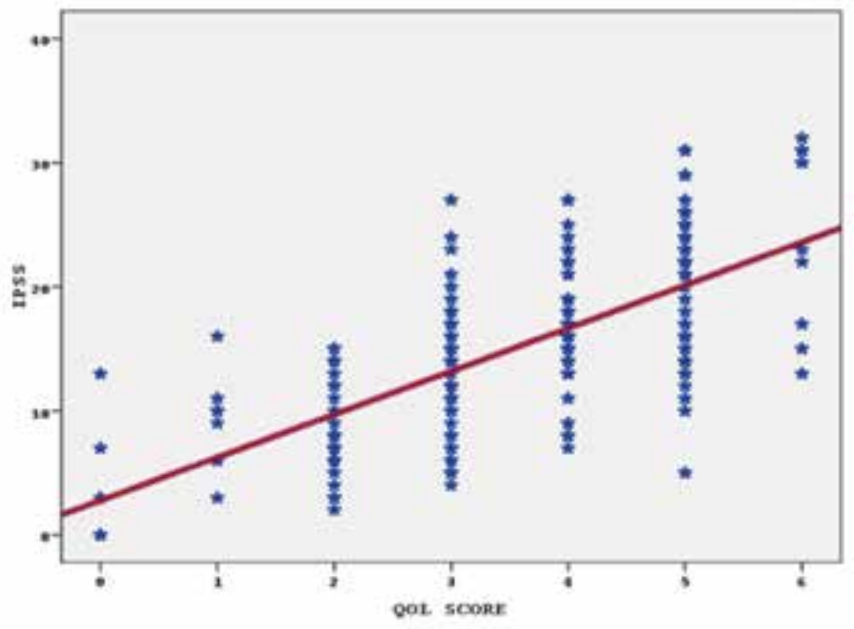

Figure 2. Positive correlation between IPSS and QoL scores ( $r=0.673$; $p=0.001 ; p<0.01)$ and high in $36(17 \%), 125(59 \%)$, and 52 (24\%) men, respectively]. However, patients with severe IPSS had severe ED (39\%-14 cases). Overall high IPSSs were significantly associated with low IIEF scores $(r=-0.198 ; p=0.004 ; p<0.01)$ (Figure 1). High IPSSs were also correlated with the low QMax values in uroflowmetry. 7\% (7/90 cases) of the patients had IPSSs more than $15 \mathrm{ml} / \mathrm{sec}$ and 18\% (12/66 cases) had IPSSs less than $10 \mathrm{ml} / \mathrm{sec}$. In addition, an association between the severity of ED and LUTS was observed ( $p<0.05$ ) (Table 3 ). Evaluation of IPSS and IIEF scores are shown in Table 4.

There was a significant correlation between age and IIEF scores ( $r=-$ $0.396 ; p=0.001 ; p<0.01$ ) but there was not any significant correlation between age and IPSS $(r=0.12 ; p=0.082 ; p>0.05)$. IPSSs and IIEF scores significantly correlated with nocturia in both groups $(r=0.631$; $p=0.001 ; p<0.01$ and $r=-0.027 ; p=0.001 ; p<0.01$, respectively). A negative correlation was found between IPSS and QMax ( $r=-0.308$; $p=0.001 ; p<0.01)$, and a positive correlation was observed between IIEF and $\mathrm{OMax}(r=0,135 ; p=0.049 ; p<0.05)$. In addition and interestingly, there were no statistically significant correlations between DM- HT groups and IPSS-IIEF combination groups ( $p>0.05)$. A significant positive correlation was observed between the QoL and IPSS ( $r=0.673$; $p=0.001 ; p<0.01)$ and a significant negative correlation was found between QoL and IIEF scores $(r=-0.22 ; p=0.001 ; p=<0.01)$ (Figure 2).

\begin{tabular}{|c|c|c|}
\hline Variables & Min-Max & Mean \pm SD \\
\hline Age (year) & $39-79$ & $60.38 \pm 7.53$ \\
\hline Nocturia & $0-7$ & $2.76 \pm 1.51$ \\
\hline IPSS & $0-32$ & $14.87 \pm 6.90$ \\
\hline IIEF & 530 & $14.9 \pm 8.10$ \\
\hline $\operatorname{Omax}(\mathrm{ml} / \mathrm{s})$ & $2.3-42.0$ & $14.45 \pm 6.74$ \\
\hline QOL Score & $0-6$ & $3.48 \pm 1.35$ \\
\hline \multirow[t]{2}{*}{ Timed micturition (s) } & $1-480$ & $33.47 \pm 60.86$ \\
\hline & $n(\%)$ & $\%$ \\
\hline \multirow{4}{*}{ Disease } & 132 & 62 \\
\hline & 47 & 22 \\
\hline & 18 & 8.5 \\
\hline & 16 & 7.5 \\
\hline
\end{tabular}

Table 2. Distribution of the comorbidities

\begin{tabular}{|l|l|l|c|}
\hline Variable & $\begin{array}{l}\text { Subjects } \\
\text { without ED }\end{array}$ & $\begin{array}{l}\text { Subjects } \\
\text { with ED }\end{array}$ & Total number \\
\hline No comorbidity & & & $62 \%(n=132)$ \\
\hline HT & 29 & 18 & $22 \%(n=47)$ \\
\hline Disease DM & 11 & 7 & $8.5 \%(n=18)$ \\
\hline DM+HT & 11 & 5 & $7.5 \%(n=16)$ \\
\hline Total & $50 / 147(34 \%)$ & $30 / 66(45 \%)$ & $100 \%(n=213)$ \\
\hline
\end{tabular}

DM: Diabetes mellitus, HT: hypertension, ED: erectile dysfunction 


\section{Discussion}

A large population of elderly people is affected by several prevalent urological diseases such as $\mathrm{BPH}$, urinary incontinence, prostate cancer, erectile dysfunction and various manifestations of hormonal decline. Aging men represent an increasing professional responsibility for the urologist and demand awareness of public health services.

LUTS and ED are highly widespread and bothersome clinical conditions affecting aging men with the incidence dramatically increasing after the middle age period. LUTS are a troublesome condition of all ages and in both gender and may cause anxiety and depression (7). ED is not a life-threatening disorder, but it influences the daily routine, social interactions, well-being and OoL of men (8). However, many men continue to be sexually active well into their late decades and preservation of sexual function should be an important consideration in QoL of elderly people. Nevertheless, the degree of sexual function or dysfunction in the elderly is also subject to cultural and social variation for obtaining reliable data. The Massachusetts Male Aging Study (MMAS) found that $52 \%$ of men between the ages of 40 and 70 years reported $E D$ with $9.6 \%$ having mild, $22.2 \%$ moderate and $17.2 \%$ complete or severe ED (9). The age-adjusted overall prevalence of ED in Turkey was $69.2 \%$ in men aged $>40$ years (mild $33.2 \%$, moderate $27.5 \%$, severe $8.5 \%$ ) and increased with age (10).

\section{Table 3. Relationship between IPSS and severity of erectile} dysfunction

\begin{tabular}{|l|l|l|l|}
\hline Variable (total $n=213)$ & IIEF (Severe ED) & $\%$ & $p$ \\
\hline Low $(n=36,17 \%)$ & 4 & 11 & \\
\hline IPSS Intermediate $(n=125,59 \%)$ & 10 & 8 & $p<0.01^{*}$ \\
\hline High $(n=52,24 \%)$ & 14 & 36 & \\
\hline Qmax $>15 \mathrm{ml} / \mathrm{s}$ & $7 / 90$ & 7 & $p<0.05^{* *}$ \\
\hline \multicolumn{1}{|c|}{$<10 \mathrm{ml} / \mathrm{s}$} & $12 / 66$ & 18 & \\
\hline
\end{tabular}

IPSS: International prostate symptom score, IIEF: International index of erectile function, 0max: maximum urinary flow, ED: erectile dysfunction

Pearson correlation coefficient ${ }^{*} p<0.01$, Spearman's correlation analysis ${ }^{* *} p<0.05$
It is estimated that approximately 90\% of men between 45 and 80 years of age have LUTS. The BPH registry and patient survey of 6.184 patients reported that 33\% of men had mild (IPSS $<7$ ), 52\% had moderate (IPSS 8-19), and 15\% had severe LUTS (IPSS $\geq 20$ ) (11). Occurrence of LUTS increases with age for almost all racial/ ethnic groups (range: $32-56 \%$ ) with the prevalence of LUTS in the United States highest among Hispanic men, then Blacks, Asians and Caucasians (12). The IPSS assesses urinary flow, poor bladder emptying, intermittency, hesitancy, urgency, frequency and nocturia. LUTS with an IPSS of $\geq 8$ are regarded as symptomatic. IPSS is not specific for symptoms secondary to BPH, but can be used to evaluate overactive bladder, nocturnal polyuria, chronic pelvic pain syndrome and many other pathologies. It is difficult to differentiate all these conditions associated with sexual dysfunction.

It has been proposed that the severity of urinary symptoms is correlated with the degree of erectile dysfunction. However, medical treatment of LUTS has been shown to decrease the severity of ED $(13,14) .12815$ men (aged 50-80 years) in the United States and six European countries were analysed by Rosen at al.. This cohort study is the largest multinational survey of the aging male (MSAM-7). 31\% of respondents had moderate to severe LUTS and $48.7 \%$ reported on difficulties achieving an erection; 10\% reported on a complete ED. Within each age category, LUTS were clearly identified as one of the risk factors for ED and the severity of ED increased incrementally with the severity of LUTS $(15,16)$. Similarly, there were statistically significantly negative correlations between IPSS and IIEF scores in our study.

Several theories are propounded for the association between LUTS and ED. Penile erection requires the relaxation of trabecular and arterial smooth muscle. The activation of sacral parasympathetic outflow and the inhibition of sympathetic input is believed to initiate and sustain penile smooth muscle relaxation and, therefore, penile erection. First theory about pathophysiology of both conditions is the role of alpha receptors with pelvic sympathetic overactivity. Raised

Table 4. Evaluation of International prostate symptom score and International index of erectile function scores

\begin{tabular}{|c|c|c|c|c|}
\hline & \multicolumn{2}{|l|}{ IPSS } & \multicolumn{2}{|l|}{ IIEF } \\
\hline & ar & $\mathrm{p}$ & $\mathrm{ar}$ & $p$ \\
\hline Age (year) & $b_{0.120}$ & 0.082 & -0.396 & $0.001^{* *}$ \\
\hline Nocturia & 0.631 & $0.001^{* *}$ & -0.227 & $0.001^{* *}$ \\
\hline Qmax & -0.308 & $0.001^{* *}$ & 0.135 & $0.049^{*}$ \\
\hline \multirow[t]{2}{*}{ QoL Score } & 0.673 & $0.001^{* *}$ & -0.22 & $0.001^{* *}$ \\
\hline & Mean \pm SD & $p$ & Mean \pm SD & $p$ \\
\hline \multirow{4}{*}{$\begin{array}{l}\text { Disease } 1-\text { None }(n=132) \\
\text { 2-HT }(n=47) \\
\text { 3-DM }(n=18) \\
\text { 4-HT+DM }(n=16)\end{array}$} & $13.91 \pm 6.53(14.0)$ & $\mathrm{c} 0.012^{*}$ & $43.11 \pm 21.57(51.0)$ & \multirow[t]{4}{*}{$\mathrm{d} 0.236$} \\
\hline & $15.15 \pm 7.25(15.0)$ & Post Hoc; & $40.02 \pm 23.91(47.0)$ & \\
\hline & $18.78 \pm 7.29(19.5)$ & $1<3$ & $34.28 \pm 22.58(35.5)$ & \\
\hline & $17.56 \pm 6.72(16.5)$ & & $37.12 \pm 20.31(46.0)$ & \\
\hline \multicolumn{5}{|c|}{$\begin{array}{l}a_{r}=\text { Spearman correlation coefficient, } \quad b_{r}=\text { Pearson correlation coefficient, } \\
\text { Coneway ANOVA test* } \quad p<0.05, \quad d_{K r u s k a l} \text { Wallis test **p<0.01 } \\
\text { IPSS: International prostate symptom score, IIEF: International index of erectile function, QoL: quality of life, Qmax: maximum urinary flow, } \\
\text { HT: hypertension, DM: Diabetes mellitus, SD: standard deviation }\end{array}$} \\
\hline
\end{tabular}


pelvic sympathetic tone leads to elevated local norepinephrine levels, which affects the alpha receptors in the cavernous smooth muscle and results in contraction, producing an anti-erectogenic state. Alpha-adrenergic receptor blockers stop the effect of norepinephrine and can induce erection (17). Activities aside from norepinephrin, such as increased Rho-kinase and endothelin-1 activity was proposed by experimental animal studies as second theory about the relationship between LUTS and ED. Rho-kinase activity increases calcium sensitivity of the muscle cells and, subsequently, promotes smooth muscle contraction cavernosal smooth muscle and the normal flaccid state of the penis (18).

Nitric oxide (NO) is released by nonadrenergic, noncholinergic nerves within the trabecular and penile arterial tissues. NO is also involved in the physiologic regulation of smooth muscle relaxation in the prostate. NO synthase (NOS)-containing nerves in the prostate, urethra and them bladder neck cause relaxation upon activation (19). As a third theory, decreased release of NO because of the impaired NOS in the endothelium of the pelvic organs with aging causes increased contraction of the smooth muscle cells at the bladder neck, prostate and corpus cavernosum. In other words, low levels of NO within the smooth muscle result in poor relaxation. Consequently, poor relaxation of the corpus cavernousum results in an increase of venous leakage from the penis. NO/NOS-mediated pathway is considered to play a role in the development of irritative LUTS and ED (20). Reduction of detrusor muscle overactivity, prostate smooth muscle relaxation, and normal contraction of the prostate tissue were inhibited when cGMP was increased using phosphodiesterase type-5 (PDE5) inhibitors. The relaxation of smooth muscle cells may increase blood flow through supporting LUTS vasculature system $(21,22)$.

A weak urine stream is one of the LUTS symptoms. Measuring QMax by uroflowmetry is also important in defining LUTS. The correlation between QMax-IPSS and QMax-IIEF scores were evaluated as statistically significant in our study. A negative correlation between high IPSS score and low levels of QMax, was observed unsurprisingly. A positive correlation was observed between IIEF scores and QMax levels. The similar result showing the relationship between IPSS and QoL has been found in another study of Turkish population (23). To the best of our knowledge, sexual function, given its importance in maintaining QoL of the male patients, should be taken into account in the initial evaluation of LUTS and in the choice of treatment offered to the patient.

QoL of the patients associated with LUTS was found to be significantly associated with ED in this study. Some studies have shown an independent effect of IPSS in predicting ED $(24,25,26)$. Our results further demonstrated the irritative LUTS had more significant impact on ED prevalence in aging males. The MMAS identified HT, DM, and frequency of urination as associates of erectile disorders. Similarly, nocturia, urinary leakage, and heart disease are significant predictors of impaired sexual function in men. DM and HT associated with LUTS had no significant effect on ED in this study, unlike the other reports $(27,28)$. Limitations of our study are the selected men population who presented to a prostate assessment clinic. They would therefore be likely to be more bothered by their urinary symptoms than the general population and almost half of the men attending the clinic were probably sexually inactive (usually single men due to partner's death, divorce, separation, etc). The follow-up IPSS questionnaires after treatment with an alpha-blocker could be used for assessing the improvement of ED. Additionally, LUTS and sexual dysfunction in postmenopausal women could be studied and compared with that in elderly men population (29). Furthermore, large-scale prospective studies are clearly needed.

\section{Conclusion}

As a conclusion, the data acquired in this study confirmed that ED and LUTS are associated clinical conditions. Additionally, IPSS-QoL, and uroflowmetry results were significantly related with erectile function. To the best of our knowledge, sexual history and therapeutical treatment of ED are important in aging men for better QoL. The association between LUTS and ED requires further epidemiological and experimental studies to better understand the possible causal relationship.

Ethics Committee Approval: HNEAH-KAEK 2014/03-Date:27/01/2014

Concept: Levent Verim

Design: Asıf Yıldırım

Data Collection or Processing: Asıf Yıldırım, Cengiz Çanakcı

Analysis or Interpretation: Levent Verim, Erem Kaan Başok

Literature Search: Sarp Korcan Keskin, Cengiz Çanakcı

Writing: Levent Verim

Peer-review: Externally peer-reviewed.

Conflict of Interest: No conflict of interest was declared by the authors.

Financial Disclosure: The authors declared that this study has received no financial support.

\section{References}

1. Kendirci M, Asci R, Yaman O, Cayan S, Orhan I, Usta MF, Ekmekcioglu 0 , Kadioglu A. Prevalence of male pelvic dysfunction: results from the Turkish society of andrology male sexual health study group. Andrology 2014;2:219-224.

2. Yassin A, Saad F, Hoesl CE, Traisch AM, Hammadeh M, Shabsigh R. Alphaadrenoceptors are a common denominator in the pathophysiology of erectile function and BPH/LUTS-implications for clinical practice. Andrologia 2006;38:1-12.

3. Khoo J, Piantadosi C, Worthley S and Wittert GA. Effects of a low-energy diet on sexual function and lower urinary tract symptoms in obese men. Int Jou Obesity 2010;34:1396-1403.

4. Demir O, Akgul K, Akar Z, Cakmak O, Ozdemir I, Bolukbasi A, Can E, Gumus $\mathrm{BH}$. Association between severity of lower urinary symptoms,erectile dysfunction and metabolic syndrome. Aging Male 2009;12:29-34.

5. Cappelleri JC, Rosen RC, Smith MD, Mishra A, Osterloh IH. Diagnostic evaluation of the erectile function domain of the International Index of Erectile Function. Urology 1999;54:346-351.

6. Barry M, Fowler FJ, O'Leary M. The American Urological Association symptom index for benign prostatic hyperplasia. J Urol 1992;148:15491557.

7. Coyne KS, Wein AJ, Tubaro A, Sexton CC, Thompson CL, Kopp ZS, Aiyer LP. The burden of lower urinary tract symptoms: evaluating the effect of LUTS on health-related quality of life, anxiety and depression: EpiLUTS. BJU Int 2009;103 Suppl 3:4-11.

8. Salonia A, Castagna $G$, Saccà $A$, Ferrari $M$, Capitanio $U$, Castiglione $F_{1}$ Rocchini L, Briganti A, Rigatti P, Montorsi F. Is erectile dysfunction a reliable proxy of general male health status? The case for the International Index of Erectile Function-Erectile Function domain. J Sex Med 2012:9:27082715. 
9. O'Donnell AB, Araujo AB, Goldstein I, McKinlay JB. The validity of a single-question self-report of erectile dysfunction. Results from the Massachusetts Male Aging Study. J Gen Intern Med 2005;20:515-519.

10. Akkus E, Kadioglu A, Esen A, Doran S, Ergen A, Anafarta K, Hattat H; Turkish Erectile Dysfunction Prevalence Study Group. Prevalence and correlates of erectile dysfunction in Turkey: a population-based study. Eur Urol 2002;41:298-304.

11. Roehrborn CG, Nuckolls JG, Wei JT, Steers W; BPH Registry and Patient Survey Steering Committee. The benign prostatic hyperplasia registry and patient survey: study design, methods and patient baseline characteristics. BJU Int 2007;100:813-819.

12. Park HJ, Won JE, Sorsaburu S, Rivera PD, Lee SW. Urinary Tract Symptoms (LUTS) Secondary to Benign Prostatic Hyperplasia (BPH) and LUTS/BPH with Erectile Dysfunction in Asian Men: A Systematic Review Focusing on Tadalafil. World J Mens Health 2013;31:193-207.

13. Carson CC. Combination of phosphodiesterase- 5 inhibitors and alphablockers in patients with benign prostatic hyperplasia: treatments of lower urinary tract symptoms, erectile dysfunction, or both? BJU Int 2006;97:39-43.

14. Kumar $R$, Nehra $A$, Jacobson DJ, McGree ME, Gades NM, Lieber MM, Jacobsen SJ, St. Sauver JL. $\alpha$-Blocker Use is Associated with Decreased Risk of Sexual Dysfunction. Urology 2009;74:82-87.

15. Rosen R, Altwein J, Boyle P, Kirby RS, Lukacs B, Meuleman, et al. Lower urinary tract symptoms and male sexual dysfunction: the multinational survey of the aging male (MSAM-7). Eur Urol 2003;44:637-649.

16. Glina S, Santana AW, Azank F, Mello LF, Moreira ED, Jr. Lower urinary tract symptoms and erectile dysfunction are highly prevalent in ageing men. BJU Int 2006;97:763-765.

17. Levin RM, Wein AJ. Adrenergic alpha receptors outnumber beta receptors in human penile corpus cavernosum. Invest Urol 1980;18:225-226.

18. Wingard CJ, Husain S, Williams J, James S. RhoA-Rho kinase mediates synergistic ET-1 and phenylephrine contraction of the rat corpus cavernosum. Am J Physiol Regul Integr Comp Physiol 2003;285:11451152.

19. McVary K. Lower urinary tract symptoms and sexual dysfunction: epidemiology and pathophysiology. BJU Int 2006;97 Suppl 2:23-8; discussion 44-5.
20. Kedia GT, Uckert S, Jonas U, Kuczyk MA, Burchardt M. The nitric oxide pathway in the human prostate: clinical implications in men with lower urinary tract symptoms. World J Urol 2008;26:603-609.

21. Takeda M, Tang R, Shapiro E, Burnett AL, Lepor H. Effects of nitric oxide on human and canine prostates. Urology 1995;45:440-446.

22. Liguori G, Trombetta C, De Giorgi G, Pomara G, Maio G, Vecchio D, Ocello G, Ollandini G, Bucci S, Belgrano E. Efficacy and safety of combined oral therapy with tadalafil and alfuzosin: an integrated approach to the management of patients with lower urinary tract symptoms and erectile dysfunction. Preliminary report. J Sex Med 2009;6:544-552.

23. Aslan G, Cavus E, Karas H, Oner O, Duran F, Esen A. Association between lower urinary tract symptoms and erectile dysfunction. Arch Androl 2006;52:155-162.

24. Ströberg $P$, Boman $H$, Gellerstedt $M$, Hedelin H. Relationships between lower urinary tract symptoms, the bother they induce and erectile dysfunction. Scand J Urol Nephrol 2006;40:307-312.v

25. Rosen $R C$, Link $C L$, O'Leary MP, Giuliano F, Aiyer LP, Mollon P. Lower urinary tract symptoms and sexual health: the role of gender, lifestyle and medical comorbidities. BJU Int 2009;103 Suppl 3:42-47.

26. Shiri R, Hakkinen J, Koskimaki J, Huntala $H$, Auvinen $A$, Hakama $M$, Tammela TL. Association between the bothersomeness of lower urinary tract symptoms and the prevalence of erectile dysfunction. J Sex Med 2005;2:438-444.

27. Feldmann HA, Goldstein I, Hatzichristou DG, Krane RJ, McKinlay JB. Impotence and its medical and psychosocial correlates: results of the Massachusetts Male Aging Study. J Urol 1994;151:54-61.

28. Song J, Shao Q, Tian Y, Na YQ, Chen S, Wang Y, Zhang XH, Hong BF, Sun WX, Diao $Y Z$. Association between lower urinary tract symptoms and erectile dysfunction in males aged 50 years and above: results from a multicenter community-based cross-sectional survey (BPC-BPH). Zhonghua Yi Xue Za Zhi 2011;91:2706-2709.

29. Borazan S, Temeltaş G, Üçer O, Hekimsoy Z, Şenol E. Assessment of Lower Urinary Tract Symptoms and Sexual Function in Women with Metabolic Syndrome. Journal of Urological Surgery 2015;1:13-16. 